\title{
Penggunaan Gray Level Co-Occurance Matrix Dari Koefisien Aproksimasi Wavelet untuk Deteksi Cacat Tekstil
}

\author{
Raihan Islamadina ${ }^{1}$, Fitri Arnia ${ }^{2}$, Khairul Munadi ${ }^{3}$ \\ 1,2,3Program Pascasarjana, Magister Teknik Elektro, Universitas Syiah Kuala \\ Jl. Tgk Chik Pante Kulu No 5 Komplek Universitas Syiah Kuala Darussalam, Banda Aceh 23111 \\ ${ }^{2,3}$ Jurusan Teknik Elektro, Fakultas Teknik, Universitas Syiah Kuala \\ Jl. T. Syech Abdurrauf No 7, Darussalam, Banda Aceh 23111 \\ E-mail: ${ }^{1}$ raihan.heri@yahoo.co.id, ${ }^{2}$ fitri.arnia@unsyiah.net, ${ }^{3}$ munadi@unsyiah.net
}

Masuk: 22 Juli 2014; Direvisi: 25 Agustus 2014; Diterima: 28 Agustus 2014

\begin{abstract}
Textile defect detection is still carried out manually and it is hard to detect textile defect more than 60\%. Therefore, this research aims for automatic textile defect detection by using Gray Level Co-occurance Matrix (GLCM) of wavelet approximation coefficients and evaluating the performance of this approach. The textile images were tiled into eight parts, to get clearer texture defects. Each part is decomposed into two levels wavelet coefficient. GLCM calculated from the wavelet approximation coefficient level one and level two is the feature used. Each set is conducted by using one image of non-defect textile and two images of two types of defect textile. Euclidean distances between each part of non-defective image and all parts in the first and the second defective image are calculated. From the simulations, it turns out that the GLCM of wavelet approximation coefficient level two is able to detect more the $\pm 70 \%$ of the existing defects.
\end{abstract}

Keywords: textile defects, gray level co-occurance matrix (glcm), wavelet approximation coefficient, euclidean distance.

\begin{abstract}
Abstrak. Pendeteksian cacat tekstil saat ini masih dilakukan secara manual mengakibatkan seseorang sulit mendeteksi lebih dari $60 \%$ dari cacat yang ada. Untuk itu, penelitian ini menerapkan metode deteksi cacat tekstil secara otomatis menggunakan Gray Level Co-Occurance Matrix (GLCM) dari koefisien aproksimasi wavelet yang bertujuan untuk mengevaluasi analisis kinerja metode. Tahapannya, sampel citra tekstil dibagi menjadi delapan bagian untuk mendapatkan tekstur cacat yang lebih jelas. Bagian tersebut didekomposisi kedalam dua level. GLCM dihitung dari koefisien aproksimasi wavelet level satu dan dua untuk dijadikan fitur. Penelitian ini dilakukan empat set simulasi citra dengan orientasi latar berbeda. Setiap set terdiri dari satu citra noncacat dan dua jenis citra cacat. Setiap bagian citra noncacat dihitung jaraknya dengan semua bagian pada citra cacat pertama dan kedua menggunakan jarak euclidean. Hasil simulasi menunjukkan bahwa GLCM dari koefisien aproksimasi wavelet level kedua mampu mendeteksi lebih dari $70 \%$ dari cacat yang ada.
\end{abstract}

Kata Kunci: cacat tekstil, gray level co-occurance matrix ( $\mathrm{glcm}$ ), koefisien aproksimasi wavelet, jarak euclidean.

\section{Pendahuluan}

Dalam sebuah industri, kualitas suatu bahan memainkan peranan penting untuk meraih posisi pasar yang dominan. Bagi sebuah industri tekstil, pengontrolan pada proses produksi sangat dibutuhkan untuk menghasilkan kualitas produk yang baik (tidak cacat). Saat ini, pemeriksaan produk dalam industri tekstil masih dilakukan secara manual. Meskipun pemeriksaan manual dianggap baik, namun juga memiliki berbagai kendala seperti kelelahan dan kebosanan manusia dalam pemeriksaan pola kain yang sama dan berulang-ulang, ketidakkonsistensian dalam kinerja dan tingginya biaya pemeriksaan (Raheja dkk, 2013). Secara 
umum, akan sulit bagi seseorang untuk mendeteksi lebih dari $60 \%$ dari cacat yang ada, dengan kain lebih lebar dari 2 meter, dan bergerak dengan kecepatan lebih cepat dari 30 meter/menit (Raheja dkk, 2013). Oleh sebab itu, dibutuhkan otomatisasi deteksi kesalahan berbasis komputer yang mampu melakukan pengenalan cacat atau kerusakan pada tekstil dengan tingkat akurasi yang lebih tinggi dari manusia.

Selama beberapa tahun terakhir, GLCM dan wavelet telah digunakan untuk mendeteksi cacat tekstil. Menurut Raheja, otomatisasi deteksi kecacatan menggunakan metode Gray Level Co-Occurance Matrix (GLCM) mampu mendeteksi cacat tekstil berdasarkan pengukuran fitur tekstur dalam bentuk matrik yang memiliki dua parameter berupa jarak interpiksel (d) dan orientasi interpiksel $(\theta)$. Dalam penelitian tersebut, sampel tekstil yang digunakan berjumlah 60 citra yang terbagi dalam 30 citra cacat dan 30 citra noncacat dengan ukuran 512 x 512 piksel. Citra cacat dan citra noncacat kemudian dibandingkan sesuai dengan jenis kain dan latar yang sama. Hasilnya, dalam implementasi tersebut GLCM mampu menghasilkan akurasi deteksi cacat yang tinggi (Raheja dkk, 2013). Selanjutnya, Narges melakukan otomatisasi menggunakan metode wavelet yang membagi data menjadi beberapa komponen frekuensi yang berbeda-beda dan setiap komponen tersebut dianalisis menggunakan resolusi yang sesuai dengan skalanya. Sehingga pendeteksian cacat tekstil dengan memilih sebuah subset yang sesuai dari koefisien wavelet melalui algoritma genetik menghasilkan fungsi yang paling cocok berupa fungsi entropi (Narges dkk, 2011). Penelitian Syihabuddin, menyatakan bahwa otomatisasi komputer dari penggunaan citra tekstil baik yang cacat maupun noncacat, diukur dan dihitung jarak kemiripannya antara dua fitur yang berbeda dari fitur masukan (uji) dengan fitur citra yang ada dalam basis data. Untuk mengukur jarak kemiripan antara fitur citra masukan dengan fitur citra yang ada dalam basis data digunakan jarak euclidean (euclidean distace) sebagai parameter (Syihabuddin, 2012). Pada penelitian lain, histogram dari koefisien aproksimasi wavelet dua tingkat digunakan sebagai fitur untuk mendeteksi cacat tekstil. Penelitian ini menggunakan citra noncacat dan empat kelompok cacat tekstil yang berbeda berupa cacat lubang, cacat tinta, cacat kotoran dan cacat benang lepas. Citra noncacat yang digunakan sebagai referensi didekomposisikan dua tingkat dengan wavelet daubechies. Kemudian histogram normalisasi dari sub-band aproksimasi dua dihitung dan disimpan dalam basis data. Selanjutnya, jarak antara fitur tekstil citra referensi dengan fitur tekstil citra cacat dihitung menggunakan jarak euclidean yang digunakan sebagai parameter evaluasi. Hasilnya, untuk citra kelompok cacat tinta dan kelompok cacat lubang mencapai tingkat kebenaran deteksi sebesar 100\% (Arnia dkk, 2014).

Pada penelitian ini, deteksi kecacatan secara otomatis diterapkan dengan metode GLCM dari koefisien aproksimasi wavelet sebagai metode ekstraksi fiturnya. Sampel citra yang digunakan berupa citra cacat tinta dan citra cacat kotoran yang terdiri dari jenis kain yang sama tetapi berbeda orientasi latarnya. Citra tekstil tersebut kemudian didekomposisi menjadi dua level, sehingga fitur tekstil memiliki ukuran yang lebih kecil, lebih efisien dalam pengolahan (perhitungan) dan penyimpanan. Selanjutnya, GLCM dihitung dari koefisien aproksimasi wavelet untuk dijadikan fitur. Nilai jarak kemiripan antara fitur tekstil citra basis data dengan fitur citra uji dihitung menggunakan jarak euclidean. Hasilnya, penelitian ini menunjukkan deteksi cacat yang lebih baik untuk metode GLCM dari koefisien aproksimasi wavelet daripada metode GLCM yang diterapkan secara langsung.

\section{Tinjauan Pustaka}

\subsection{Gray Level Co-Occurance Matrix (GLCM)}

Gray Level Co-Occurance Matrix (GLCM) merupakan teknik analisis tekstur orde kedua dalam bentuk matrix co-occurance yang mempertimbangkan korelasi antar 2 piksel dengan nilai intensitas tertentu yang memiliki hubungan jarak dan arah tertentu. Biasanya, ada empat arah yang digunakan, yaitu $0^{0}, 45^{\circ}, 90^{\circ}$ dan $135^{\circ}$ yang ditunjukkan pada Gambar 1 (Tahir dkk, 2005). Adapun cara membentuk GLCM, dimisalkan sebuah citra I berukuran 5 x 4 piksel, kemudian ditetapkan jaraknya 1 piksel dan arahnya adalah $0^{\circ}$, maka GLCM nya dapat dilihat pada Gambar 2. 


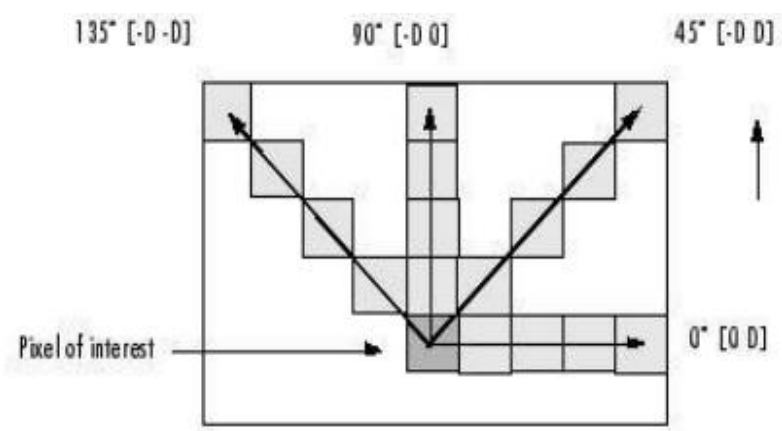

Gambar 1. Korelasi antara Sepasang Piksel dengan Jarak dan Arah Tertentu (Tahir dkk, 2005)

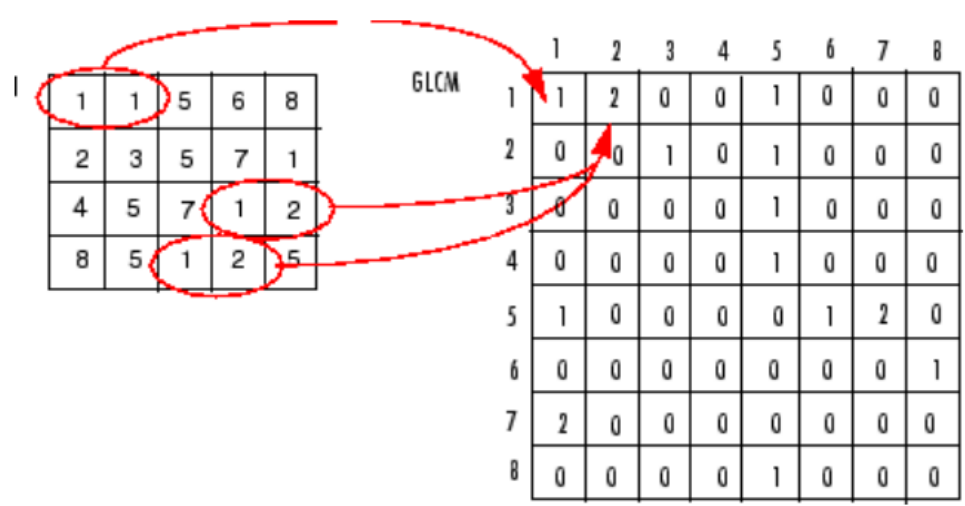

Gambar 2. Perhitungan GLCM dengan Arah 0(Haralick, 1979)

Gambar 2 menunjukkan cara perhitungan nilai GLCM dalam citra I. Dalam GLCM, elemen $(1,1)$ bernilai 1 karena hanya ada satu contoh pada citra I yang bernilai 1 dan 1 . Sementara elemen $(1,2)$ bernilai 2 karena ada dua contoh 1 dan 2 pada citra I. kemudian elemen $(1,3)$ bernilai 0 karena tidak ada contoh 1 dan 3 pada citra I dan begitu seterusnya hingga mencapai elemen $(8,8)$ (Haralick, 1979).

Analisis tekstur GLCM lebih baik dalam merepresentasikan tekstur citra dalam parameter-parameter terukur, seperti maximum probability, contrast, correlation, homogeneity, entropy, energy, dissimilarity dan Inverse Difference Moment (Tahir dkk, 2005).

\subsection{Transformasi Wavelet}

Transformasi wavelet merupakan suatu fungsi matematika yang membagi data menjadi beberapa komponen frekuensi yang berbeda-beda dan menganalisis setiap komponen tersebut dengan resolusi yang sesuai dengan skalanya (Polikar, 1995). Transformasi wavelet menggunakan dua komponen dalam transformasi, yaitu fungsi skala (scalling function) disebut juga lowpass filter dan fungsi waktu (wavelet function) yang disebut juga highpass filter. Scalling function dapat membentuk wavelet bermacam-macam jenisnya, seperti wavelet Haar dan Daubechies. Wavelet Daubechies adalah filter wavelet yang digunakan untuk pemampatan data citra. Daubechies memiliki ordo yang menggambarkan jumlah koefisien filternya. Sifat polinomial yang dimiliki oleh wavelet akan berpengaruh dalam penentuan jumlah koefisien filter wavelet. Semakin besar jumlah filter yang dimiliki, maka semakin baik filter tersebut dalam melakukan pemilihan frekuensi (Meutia, 2009).

Wavelet Daubechies berasal dari sistem Haar ditulis sebagai ' $\mathrm{dbN}$ ' dengan N menunjukkan ordo 2 koefisien (db2) memiliki scaling function dengan koefisien low-pass. Lihat persamaan 1 sampai dengan persamaan 4. Nilai koefisien high-pass (wavelet function) dengan $\mathrm{N}=2$ atau berodo 2 adalah $\mathrm{g} 0=\mathrm{h} 3, \mathrm{~g} 1=-\mathrm{h} 2, \mathrm{~g} 2=\mathrm{h} 1, \mathrm{~g} 3=-\mathrm{h} 0$, dimana $\mathrm{g}=$ high-pass dan $\mathrm{h}=$ low-pass. Nilai-nilainya ditunjukkan pada transformasi matrik pada persamaan 5. Ingrid Daubechies telah mengklasifikasikan koefisien secara numerik untuk $\mathrm{N}=4$ atau berordo 4 pada Tabel 1 (Meutia, 2009). 


$$
\begin{aligned}
& h(0)=\frac{1+\sqrt{3}}{4 \sqrt{2}} \\
& h(1)=\frac{3+\sqrt{3}}{4 \sqrt{2}} \\
& h(2)=\frac{3-\sqrt{3}}{4 \sqrt{2}} \\
& h(3)=\frac{1-\sqrt{3}}{4 \sqrt{2}}
\end{aligned}
$$

Tabel 1. Koefisien db4

\begin{tabular}{rcc}
\hline \multicolumn{2}{c}{ Low pass } & Koefisien \\
\hline $\mathbf{N = 4}$ & $\mathrm{h}(0)$ & 0,230377813309 \\
\hline $\mathrm{h}(1)$ & 0,714846570553 \\
\hline $\mathrm{h}(2)$ & 0,630880077679 \\
\hline $\mathrm{h}(3)$ & $-0,027983769417$ \\
\hline $\mathrm{h}(4)$ & $-0,187034811719$ \\
\hline $\mathrm{h}(5)$ & 0,030841381836 \\
\hline $\mathrm{h}(6)$ & 0,032883011667 \\
\hline $\mathrm{h}(7)$ & $-0,010597401785$ \\
\hline
\end{tabular}

\subsubsection{Dekomposisi Citra pada Transformasi Wavelet}

Dekomposisi merupakan proses pembagian sinyal menjadi frekuensi tinggi dan frekuensi rendah dengan filterisasi highpass filter dan lowpass filter. Proses dekomposisi dimulai dengan melewatkan sinyal asal melewati highpass filter dan lowpass filter. Misalkan sinyal asal ini memiliki rentang waktu frekuensi dari 0 sampai dengan $\pi \mathrm{rad} / \mathrm{s}$ dalam melewati highpass filter dan lowpass filter ini, rentang di-subsample menjadi dua, sehingga rentang frekuensi tertinggi masing-masing subsample menjadi $\pi / 2 \mathrm{rad} / \mathrm{s}$, sehingga sinyal dapat selalu disubsample oleh $2(\downarrow 2)$ dengan cara mengabaikan setiap sample yang kedua (Meutia, 2009).

$$
\begin{aligned}
& Y_{\text {tinggi }}[k]=\sum_{n} X[n] h[2 k-n] \\
& Y_{\text {rendah }}[k]=\sum_{n} X[n] g[2 k-n]
\end{aligned}
$$

Keterangan:

$$
Y_{\text {tinggi }} \operatorname{dan} Y_{\text {rendah }}=\text { hasil dari highpass filter dan lowpass filter }
$$

$X[\mathrm{n}]=$ sinyal asal $\quad h[\mathrm{n}]=$ highpass filter $\quad g[\mathrm{n}]=$ lowpass filter

Proses dekomposisi ini dapat melalui satu atau lebih tingkatan (Gambar 3). Dekomposisi satu tingkat ditulis secara matematis pada persamaan 6 dan persamaan 7. Proses dekomposisi lebih dari satu tingkat seperti Gambar 3. Prosedur dari persamaan 6 dan 7 dapat digunakan untuk perhitungan pada kolom dan baris, merupakan detil dari informasi sinyal, sedangkan merupakan taksiran kasar dari fungsi penskalaan (Meutia, 2009). 


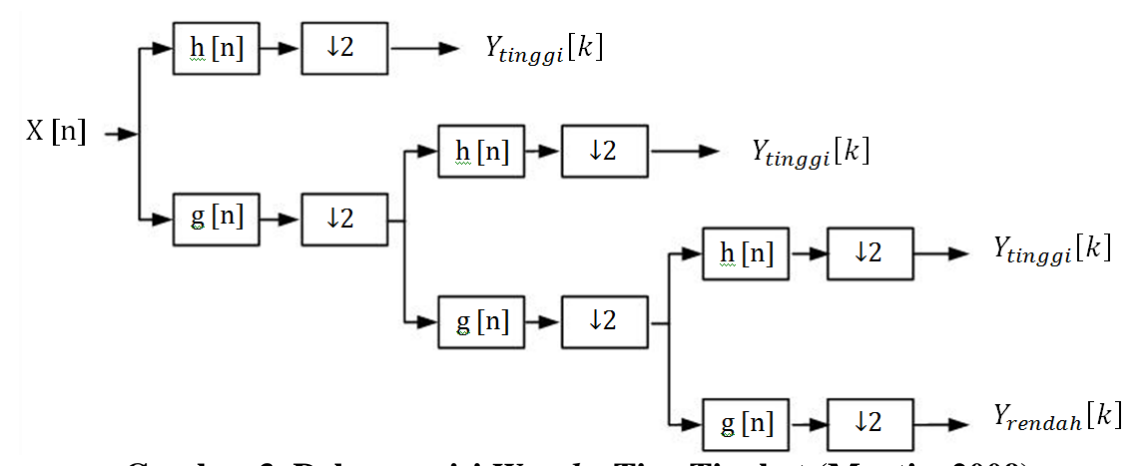

Gambar 3. Dekomposisi Wavelet Tiga Tingkat (Meutia, 2009)

\subsubsection{Komposisi Citra pada Transformasi Wavelet}

Proses komposisi diawali dengan menggabungkan koefisien transformasi wavelet diskrit yang berada pada akhir dekomposisi dengan sebelumnya meng-upsample oleh 2( $\uparrow 2)$ melalui highpass filter dan lowpass filter. Proses komposisi ini sepenuhnya merupakan kebalikan dari proses dekomposisi sesuai dengan tingkatan dari proses dekomposisi. Sehingga persamaan komposisi pada masing-masing tingkatan dapat ditulis dengan persamaan 8.

$X[n]=\sum_{k}\left(Y_{\text {tinggi }}[k] h[-n+2 k]+Y_{\text {rendah }}[k] g[-n+2 k]\right)$

Proses komposisi wavelet untuk mendapatkan sinyal asal dengan tiga tingkatan digambarkan pada Gambar 4. Komposisi dari proses dekomposisi pada Gambar 4 disebut juga Inverse Wavelet Transform. Koefisien aproksimasi dan detail (horisontal, vertikal dan diagonal) di-upsampling dan dikonvolusi dengan dua filter 1 Dimensi. Satu filter bekerja pada kolom dan yang lainnya bekerja pada baris. Proses ini diulang hingga berbentuk citra asli (Meutia, 2009).

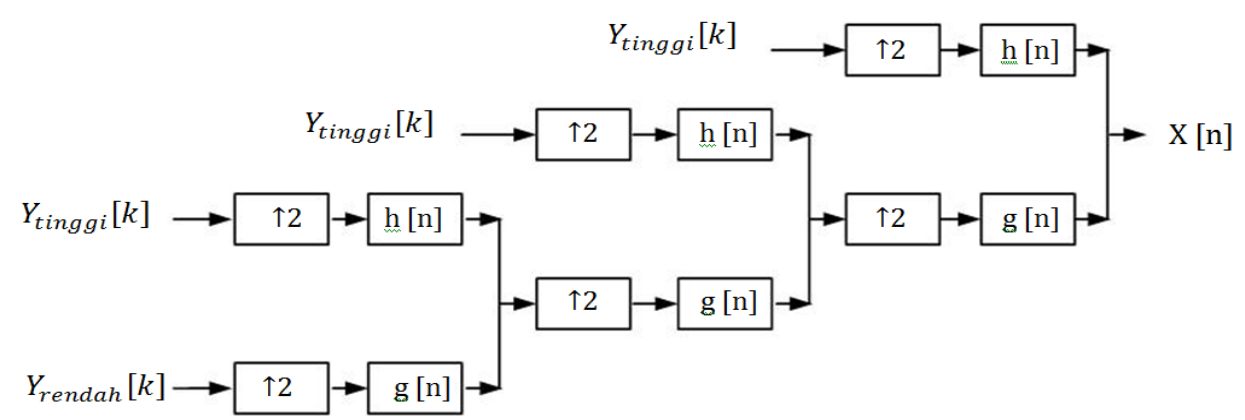

Gambar 4. Komposisi Wavelet Tiga Tingkat (Meutia, 2009)

\subsection{Jarak Euclidean (Euclidean Distance)}

Dalam program aplikasi pencarian tekstur kemiripan antara dua buah fitur dapat dihitung dengan jarak, salah satunya dengan jarak euclidean. Jarak euclidean adalah formulasi untuk menghitung nilai jarak dari dua fitur. Ruang euclidean merupakan ruang dengan dimensi terbatas yang bernilai real. Jarak euclidean digunakan untuk mengidentifikasi suatu nilai fitur masukan/uji dengan nilai fitur yang tersimpan pada basis data. Jarak Euclidean ditentukan dengan persamaan 9 dan persamaan 10 (Syihabuddin, 2012), dengan $d_{x, y}$ adalah Euclidean distance, $x$ adalah nilai fitur masukan, $y$ merupakan nilai fitur pada basis data dan $n$ adalah Jumlah nilai pada fitur.

$$
\begin{aligned}
& d_{x, y}=\sqrt{\sum_{n}\left(x_{n}-y_{n}\right)^{2}} \\
& d_{x, y}=\sqrt{\left(x_{1}-y_{1}\right)^{2}+\left(x_{2}-y_{2}\right)^{2}+\ldots+\left(x_{n}-y_{n}\right)^{2}}
\end{aligned}
$$


Persamaan 10 menjelaskan bahwa $(x)$ merupakan nilai dari fitur masukan dan $(y)$ merupakan nilai dari fitur pada basis data. Semakin kecil perbedaan antara dua buah fitur, maka jaraknya akan semakin kecil. Begitu juga sebaliknya, semakin besar perbedaan antara dua buah fitur, maka jaraknya juga akan menjadi semakin besar. Apabila dua fitur sangat mirip, maka jarak antara fitur-fiturnya mendekati 0 (nol).

\subsection{Parameter Pengukur Kinerja Identifikasi}

\subsubsection{False Acceptance Rate (FAR)}

False Acceptance Rate (FAR) berguna untuk melihat sejauh mana sistem melakukan kesalahan dalam menerima masukan, dimana citra yang seharusnya ditolak namun diterima oleh sistem. Secara matematis, FAR dihitung melalui persamaan 11 (SYRYS Technologi Corp, 2004).

$$
F A R=\frac{\text { Jumlah Citra Salah Terima }}{\text { Jumlah Seluruh Citra Pencocokan }} \times 100 \%
$$

\subsubsection{False Rejection Rate (FRR)}

False Rejection Rate (FRR) menunjukkan sistem melakukan kesalahan dalam menolak masukan, dimana citra yang seharusnya diterima namun ditolak oleh sistem. Persamaan FRR secara matematis dapat dilihat pada persamaan 12 (SYRYS Technologi Corp, 2004).

$$
F R R=\frac{\text { Jumlah Citra Salah Tolak }}{\text { Jumlah Seluruh Citra Pencocokan }} \times 100 \%
$$

\subsubsection{Distribusi FAR dan FRR}

Gambar 5 menunjukkan distribusi akurasi antara FAR yang disebut juga False Accept/False Match $(\mathrm{FAR}=\mathrm{FA}=\mathrm{FM})$ dan FRR disebut juga False Reject/False nonmatch $(\mathrm{FRR}=\mathrm{FR}=\mathrm{FNM})$ yang dinyatakan dalam nilai ambang (threshold) yang dibentuk berdasarkan nilai jarak. Nilai ambang berperan penting dalam memutuskan terjadinya kesalahan dalam hal pencocokan dan dijadikan tolak ukur untuk membedakan citra mana saja yang masuk kedalam FAR dan yang masuk kedalam FRR.

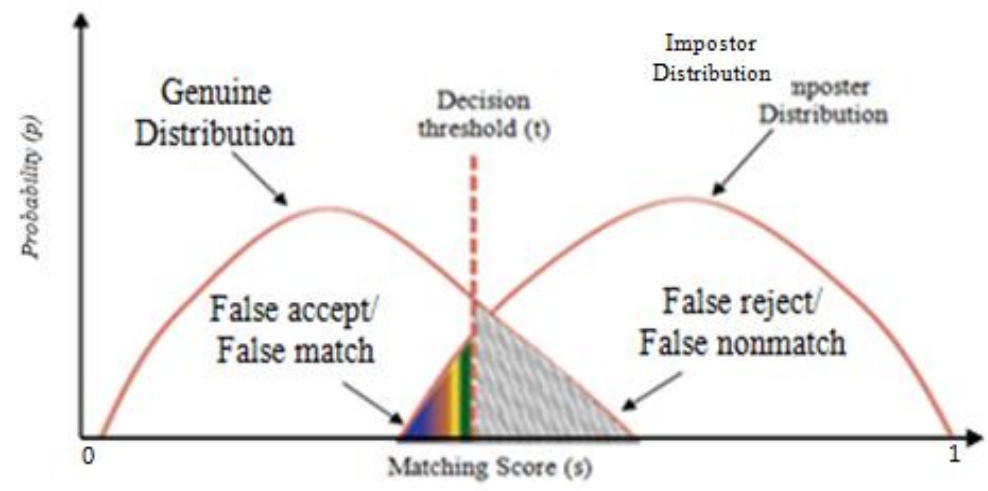

\section{Gambar 5. Kurva Distribusi FAR dan FRR (Putra, 2009)}

Daerah irisan False Match menyatakan suatu sistem keliru mengenali pola yang palsu sebagai asli. Sedangkan False Nonmatch menyatakan sistem keliru mengenali pola yang asli sebagai palsu (Putra, 2009). Pada penelitian ini, nilai sumbu x yang mendekati " 0 " dianggap genuine (tidak cacat) dan daerah yang mendekati "1" dianggap impostor (cacat). Nilai ambang (thresholding) ditentukan dengan cara manual dengan menggabungkan nilai dari fitur citra cacat dengan fitur noncacat. 


\section{Metodologi Penelitian}

\subsection{Bahan Penelitian}

Penelitian ini merupakan suatu studi penggunaan GLCM dari koefisien aproksimasi wavelet untuk deteksi cacat tekstil. Transformasi wavelet yang diterapkan dalam penelitian ini berupa transformasi wavelet daubechies dengan dua level dekomposisi. Sedangkan GLCM digunakan untuk menghitung probabilitas hubungan ketetanggaan antara dua piksel pada jarak dan orientasi sudut tertentu.

Penelitian ini dilakukan melalui empat simulasi dengan orientasi latar berbeda dari citra tekstil noncacat dan citra cacat yang berbeda (cacat tinta dan cacat kotoran) dengan jenis kain yang sama (yang ditunjukkan dalam Gambar 6 dan Gambar 7) dengan dimensi 512x768 piksel dan berkapasitas $384 \mathrm{~kb}$ yang diambil dari basis data TILDA (Textile Texture Database) version 1.0, 1996. Cacat tinta ditandai dengan noktah gelap pada citra, sedangkan cacat kotoran berupa penambahan objek putih pada citra. Alat yang digunakan dalam penelitian ini adalah komputer/laptop dengan spesifikasi yang cukup untuk mengoperasikan MATLAB 7.0,

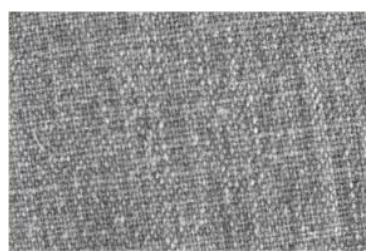

Latar simulasi pertama

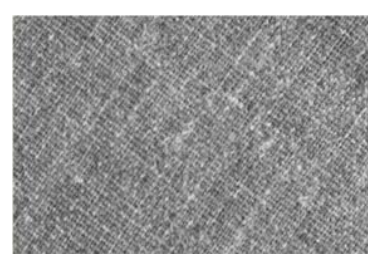

Latar simulasi kedua

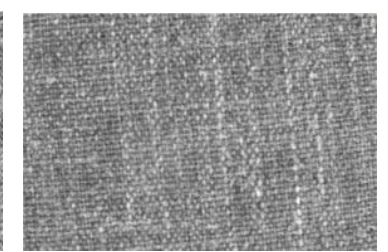

Latar simulasi ketiga

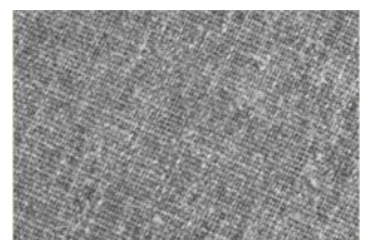

Latar simulasi keempat

Gambar 6. Sampel Citra Tekstil Noncacat dengan Orientasi Latar Berbeda (TILDA Database)

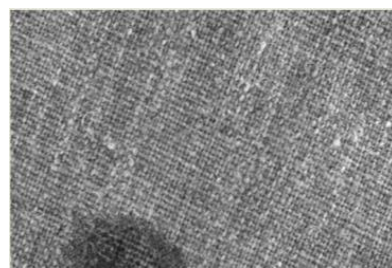

Cacat tinta

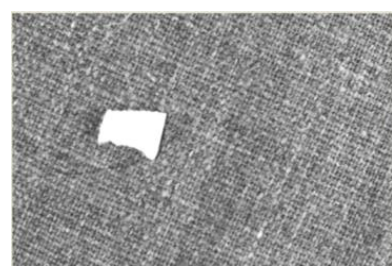

Cacat kotoran

Gambar 7. Sampel Citra Cacat Tekstil dengan Latar Keempat (TILDA Database)

\subsection{Teknik dan Prosedur Pengujian}

Gambar 8 menunjukkan rancangan metode deteksi cacat tekstil berbasis GLCM dari koefisien aproksimasi wavelet. Citra yang dimasukkan berupa citra gray scale noncacat yang ditiling kedalam delapan bagian, dan selanjutnya bagian citra tersebut didekomposisi kedalam dua level. Dekomposisi citra input level pertama menghasilkan bagian $\mathrm{LL}_{1}$ untuk bagian aproksimasi, $\mathrm{LH}_{1}$ untuk bagian detail vertikal, $\mathrm{HL}_{1}$ bagian detail horisontal dan $\mathrm{HH}_{1}$ bagian detail diagonal. Citra hasil dekomposisi level pertama menghasilkan ukuran 256x384. Selanjutnya untuk dekomposisi level kedua, hanya diambil dari $\mathrm{LL}_{1}$ dan dekomposisi menjadi $\mathrm{LL}_{2}, \mathrm{LH}_{2}, \mathrm{HL}_{2}$, dan $\mathrm{HH}_{2}$ dan hasil dekomposisi level kedua menghasilkan ukuran citra yang lebih kecil yaitu 128x192 piksel. Selanjutnya, GLCM di hitung dari $\mathrm{LL}_{1}$ dan $\mathrm{LL}_{2}$ hasil dari level pertama dan level kedua dengan nilai dari masing-masing levelnya dijadikan fitur dan dijadikan tolak ukur. Selanjutnya, dilakukan proses perhitungan fitur untuk citra cacat (citra uji) dengan proses yang sama seperti yang terjadi pada proses citra masukan (citra noncacat). Fitur citra uji (citra cacat) yang sudah mengalami proses perhitungan fitur, akan dilihat dan dibandingkan jarak kemiripannya dengan citra masukan (citra noncacat) dengan menggunakan jarak euclidean.

Dalam penelitian ini, dilakukan empat set simulasi citra dengan orientasi latar berbeda (seperti ditunjukkan dalam Gambar 6). Setiap satu set simulasi terdiri dari tiga citra yaitu satu citra noncacat dan dua citra cacat (kotoran dan tinta). Citra cacat dan citra noncacat yang telah di-tiling menjadi delapan bagian, selanjutnya dihitung fiturnya. Setiap bagian pada citra noncacat dibandingkan (perhitungan jarak) dengan semua bagian pada citra cacat pertama dan 
citra cacat kedua. Sehingga dihasilkan total perulangan simulasi sebanyak 128 kali. Kemudian, dalam setiap perulangan simulasi diterapkan (1) metode GLCM dari koefisien aproksimasi wavelet level satu, (2) metode GLCM dari koefisien aproksimasi wavelet level dua dan (3) metode GLCM yang terapkan secara langsung. Sehingga, total perulangan simulasi untuk setiap jenis tekstil adalah 128x3 (metode GLCM-LL 1 , GLCM-LL 2 dan GLCM)=384 kali. Total perulangan simulasi untuk semua jenis orientasi tekstil adalah 4x384=1536 perulangan.

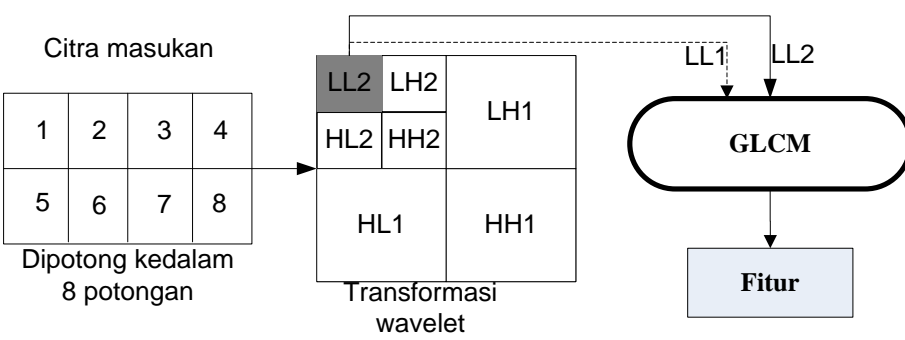

Gambar 8. Rancangan Metode Deteksi Cacat Tekstil Berbasis GLCM dari Koefisien Aproksimasi Wavelet

\section{Hasil dan Analisis}

Pada bagian ini akan dipaparkan hasil dari tiga metode yang digunakan. Kehandalan suatu sistem diketahui melalui proses perhitungan nilai FAR (False Accept) dan FRR (False Reject). Kurva distribusi antara citra noncacat (ditandai dengan warna merah) dan citra cacat (ditandai dengan warna biru) terdiri dari sumbu x untuk jarak euclidean dengan skala dari 0 sampai 1 yang berarti bahwa distribusi citra noncacat akan mendekati nilai 0 dan distribusi citra cacat akan mendekati nilai 1, dan sumbu y merupakan jumlah kemunculan jarak (frekuensi) yang terjadi dari citra noncacat dengan citra cacat. Distribusi dalam penelitian ini dipentingkan nilai FAR yang sekecil mungkin yang artinya bahwa sedikit citra cacat yang dianggap sebagai citra tidak cacat dan FRR yang juga kecil yang berarti bahwa sedikit citra noncacat dianggap sebagai citra cacat. Pada simulasi ini, nilai ambang (threshold) ditetapkan sesuai dengan garis pertemuan distribusi antara citra noncacat dan citra cacat dengan penetapkan sebesar 0,1 untuk ketiga grafik distribusi.

Gambar 9 adalah distribusi nilai jarak dari penerapan metode GLCM untuk citra cacat dan noncacat. Threshold sebesar 0,1 menghasilkan nilai FAR sebesar 6,15\% yang berasal dari jumlah citra cacat yang salah diterima oleh sistem dan dianggap sebagai citra noncacat yang dihitung dari 4 sampel citra cacat dibagi dengan 65 citra cacat, sedangkan nilai FRR sebesar $67,55 \%$ dari jumlah citra noncacat yang salah tolak dan dianggap cacat oleh sistem yang dihitung dari 152 sampel citra noncacat dibagi dengan 225 citra noncacat. Sedangkan untuk distribusi nilai jarak dari penerapan metode GLCM Aproksimasi wavelet level satu (Gambar 10) menghasilkan nilai FAR sebesar $20 \%$ yang berasal dari jumlah citra cacat yang salah diterima oleh sistem dan dianggap sebagai citra noncacat yang dihitung dari 13 sampel citra cacat dibagi dengan 65 citra cacat, sedangkan nilai FRR sebesar $63,11 \%$ dari jumlah citra noncacat yang salah tolak dan dianggap cacat oleh sistem yang dihitung dari 142 sampel citra noncacat dibagi dengan 225 citra noncacat dengan threshold 0,1 .

Selanjutnya pada Gambar 11 ditunjukkan distribusi nilai jarak dari citra cacat dengan noncacat menggunakan metode GLCM dari koefisien aproksimasi wavelet level kedua. Dengan threshold yang sama, yaitu 0,1 menghasilkan nilai FAR sebesar 1,54\% yang berasal dari jumlah citra cacat yang salah terima oleh sistem dan dianggap sebagai citra noncacat yang dihitung dari 1 sampel citra cacat dibagi dengan 65 citra cacat, sedangkan FRR bernilai 66,67\% dari jumlah citra noncacat yang salah tolak dan dianggap cacat oleh sistem yang dihitung dari 150 sampel citra noncacat dibagi dengan 225 citra noncacat.

Berdasarkan perhitungan nilai dari FAR dan FRR, didapatkan hasil dari penggunaan metode GLCM dari koefisien aproksimasi wavelet level kedua lebih bagus mendeteksi kecacatan. FAR dari jumlah citra cacat yang salah terima dan dianggap tidak cacat oleh sistem 
bernilai $1,54 \%$ yang berarti bahwa sistem mampu mendeteksi kecacatan pada suatu citra lebih dari $98,46 \%$ dari cacat yang ada.

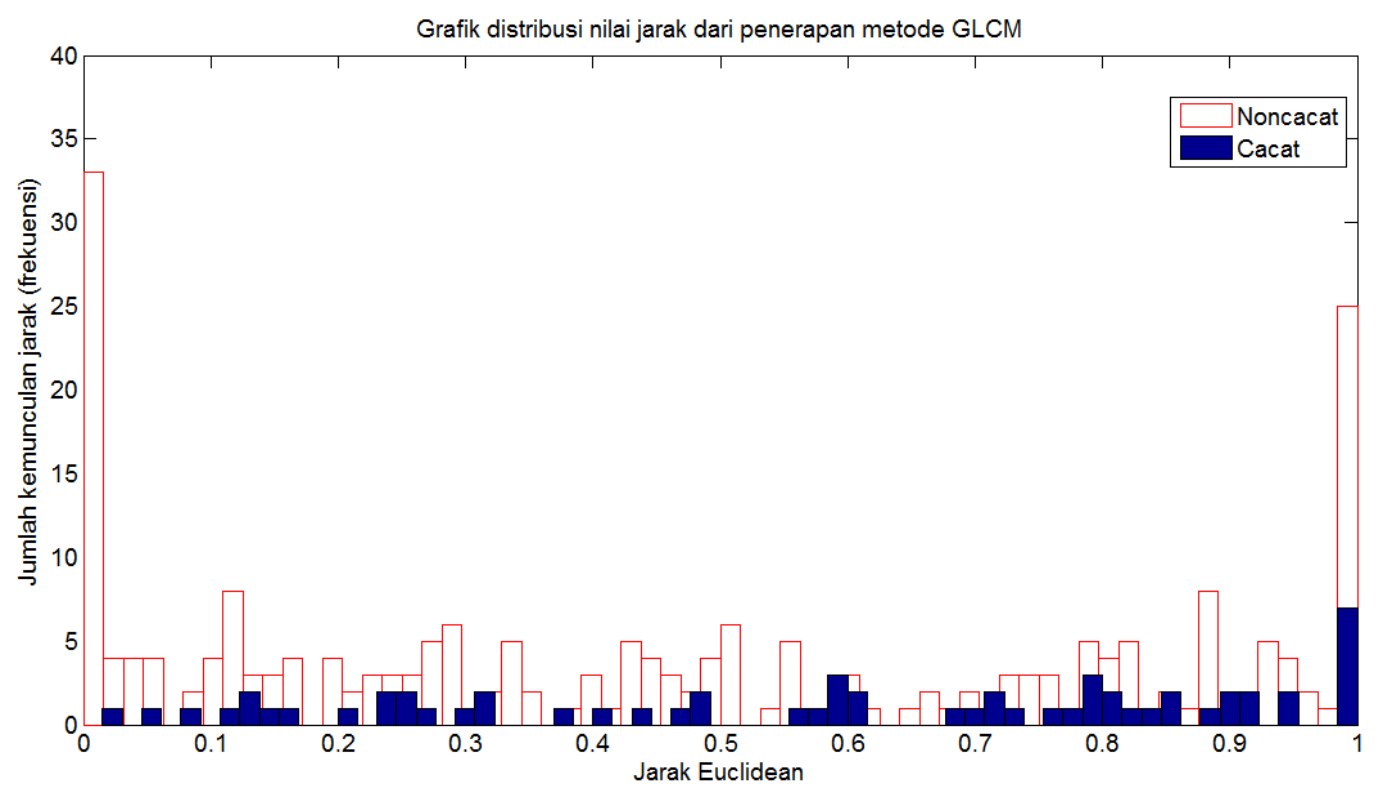

Gambar 9. Distribusi nilai jarak dari penerapan metode GLCM untuk citra cacat dan noncacat.

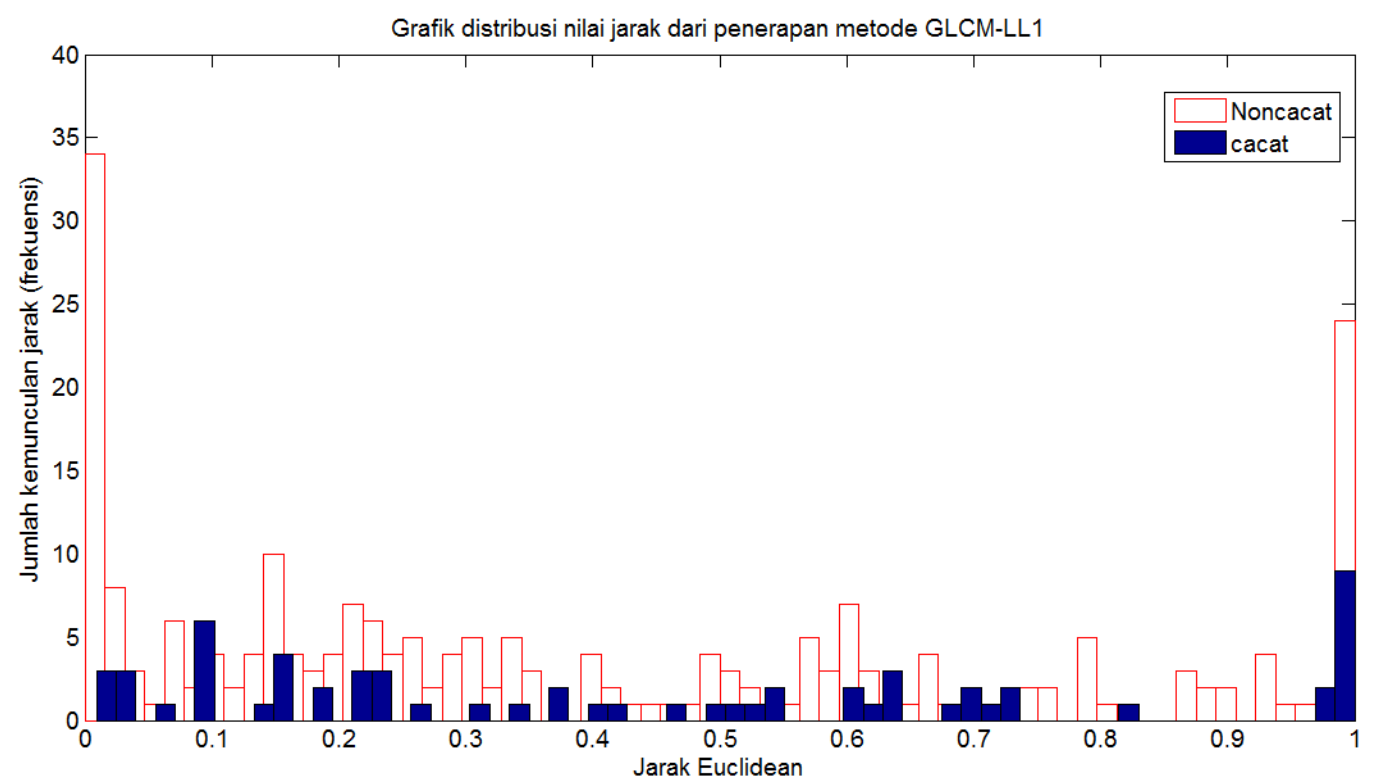

Gambar 10. Distribusi nilai jarak dari penerapan metode GLCM Aproksimasi wavelet level satu untuk citra cacat dan noncacat. 


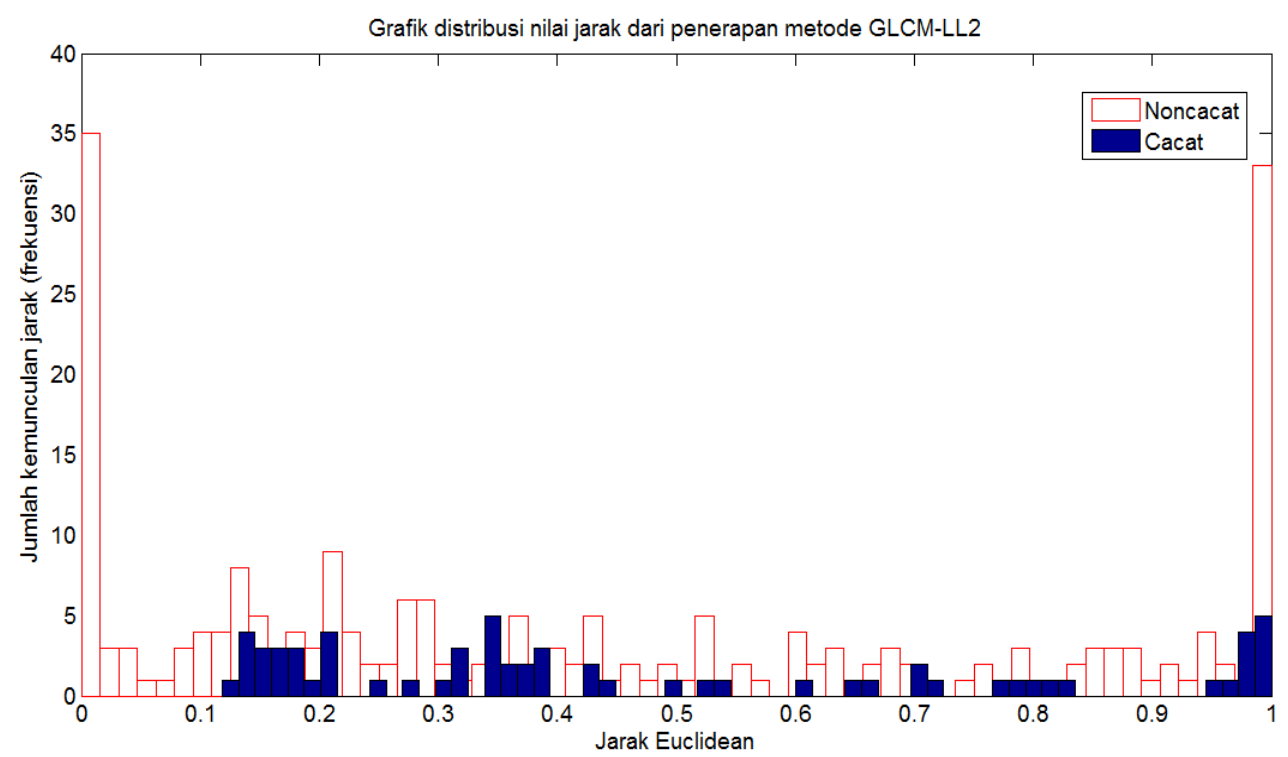

Gambar 11. Distribusi nilai jarak dari penerapan metode GLCM Aproksimasi wavelet level dua untuk citra cacat dan noncacat.

\section{Kesimpulan}

Suatu metode deteksi cacat tekstil berbasis Gray Level Co-Occurance Matrix (GLCM) dari koefisien aproksimasi wavelet telah dipaparkan dalam paper ini. Citra jenis cacat tinta dan cacat kotoran dengan empat orientasi latar yang berbeda digunakan pada penelitian ini. Hasil pengukuran jarak menunjukkan bahwa metode GLCM dari koefisien aproksimasi wavelet level kedua lebih bagus dari pada GLCM dari koefisien aproksimasi wavelet level satu dengan peningkatan deteksi cacat sebesar $\pm 18 \%$ yang berasal dari pengurangan nilai FAR level dua dengan nilai FAR level satu.

\section{Referensi}

Arnia, Fitri., Andika Saputra \& Khairul Munadi. 2014. Penggunaan Histogram dari Koefisien Aproksimasi Wavelet untuk Deteksi Cacat Tekstil. Jurnal Nasional Teknik Elektro, Vol: 3 No. 1 Maret 2014.

Haralick, R.M. 1979. Statistical and Structural Approaches to Texture. Proceedings of the IEEE, vol. 67, 1979, pp. 786-804.

Meutia, Rahmi. 2009. Aplikasi Wavelet Untuk Deteksi Tepi Pada Citra Grayscale Yang Berderau. Banda Aceh: Tugas Akhir Teknik Elektro Universitas Syiah Kuala.

Narges, H., Reza Azmi \& Boshra Pishgoo. 2011. Fabric Textile Defect Detection, By Selecting a Suitable Subset of Wavelet Coefficients, Through Genetic Algorithm. International Journal of Image Processing (IJIP), vol.5, Issue.1, pp. 25-35.

Polikar, Robi. 1995. "The Wavelet Tutorial", (Online), (http://staff.ui.ac.id/internal/131944413/ material/RobiPolikar-WaveletTutorial.pdf, diakses 29 November 2012).

Putra, Darma. 2009. Sistem Biometrika Konsep Dasar, Teknik Analisis Citra, dan Tahapan Membangun Aplikasi Sistem Biometrika. Yogyakarta: Andi.

Raheja, J. L., Kumar, S. \& Chaudhary, A. 2013. Fabric Defect Detection Based on GLCM and Gabor Filter: A Comparison. Optik, Elsevier, vol. 124, pp. 6469-6474.

Syihabuddin, Ahmad. 2012. "Analisis Cluster", (Online), (http://statistikaku.16mb.com/2012/ 03/cluster/, diakses 20 februari 2013).

SYRYS Technologi Corp. 2004. "Technical Document About FAR, FRR and EER", Version 1.0 ,

Tahir, M. A., Bouridane, A. \& Kurugollu, F. 2005. An FPGA Based Coprocessor for GLCM and Haralick Texture Features and Their Application in Prostate Cancer Classification. Springer, Analog Integrated Circuits and Signal Processing, vol. 43, pp. 205-215. 